\title{
Tsunamiens spor i grundvandet - erfaringer fra undersøgelser i Sri Lanka
}

\section{Af seniorforsker Karen G. Villholth, IWMI}

Tsunamien, som opstod efter det kæmpemæssige underjordiske jordskælv tæt ved Sumatra i det Indiske Ocean d. 24. december, 2004, forårsagede pludselig og vidtomfavnende død og ødelæggelser i sit umiddelbare kølvand i de omkringliggende lande ${ }^{[a]}$. Men efter bølgerne havde trukket sig tilbage, stod det klart, at noget andet var stærkt medtaget af tunamien, som indirekte ville påvirke den lokale befolkning i lang tid efter, nemlig grundvandet og vandforsyningen.

Konsekvenserne af tsunamien i Sri Lanka var enorme, lokalt såvel som nationalt. Flere hundred tusind mennesker omkom (estimeret til 31.000 alene i Sri Lanaka), og mange (5-6.000) blev meldt savnet og aldrig fundet, øjensynligt skyllet væk og druknet i bølgemasserne. Omfanget forekommer uforholdsmæssigt stort (se boksen nedenfor), fordi en stor del af befolkningen, ca en tredjedel, er koncentreret i kystområderne, og der er en livlig økonomisk aktivitet her - specielt fra småskala-fiskeri fra de mange små landsbyer, som ligger tæt langs kysten og fra turisthoteller og -resorts.

Ofte er fiskerierhvervet en levevej for småfiskere, som i generationer har levet af

Sri Lanka og de undersøgte områder. (Grafik: UVH efter Forfatteren)

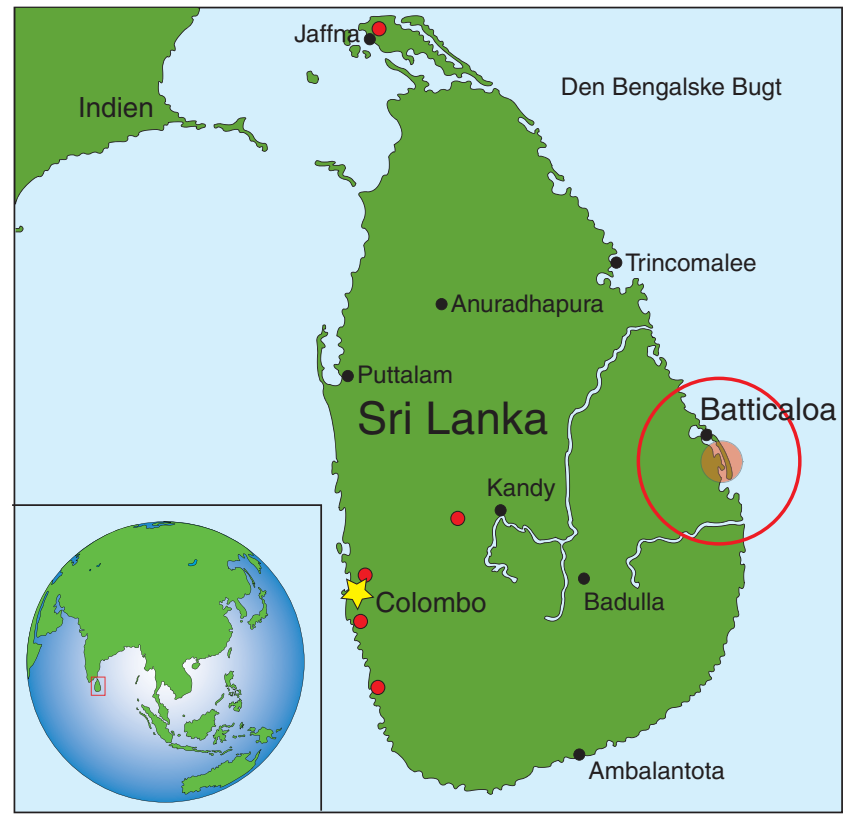

havet og brugt simple både og redskaber til at indhente deres fangst. Turistindustrien er præget af simple hytter tæt på havet eller store hotelkomplekser, hvoraf sidstnævnte blev mindst påvirket af katastrofen. Befolkningstætheden er generelt større langs kysterne, og derfor ramte tsunamien ekstra hårdt.

Tsunamien påvirkede vandforsyningen De rednings-og nødhjælpsaktiviteter, som

\section{Tsunamien påvirkede ikke store områ- der, arealmcessigt, i Sri Lanka}

Bølgerne skyllede op til 1,5 km ind i landet ${ }^{[b]}$, de fleste steder mindre, nogle steder mere - specielt hvor bølgerne af en eller anden grund havde særligt stor styrke, eller hvor flodmundinger gjorde, at effekten kunne forplante sig længere ind i landet. Dette glemmes ofte, når man i medierne hører om katastrofen og dens eftervirkninger i Sri Lanka. Efter disse får man let det indtryk, at hele, eller i hvert fald store dele af øen blev oversvømmet.
Men Sri Lanka er 1,5 gange større end Danmark i areal, har $1.600 \mathrm{~km}$ kyststrækning, mod Danmarks 7.000 $\mathrm{km}$, og regner man med, at en $1 \mathrm{~km}$ bred bræmme langs kysten i gennemsnit blev overskyllet, og at $75 \%$ af kystlinien blev ramt, specielt i den sydlige og østlige del, så svarer det til, at 1.200 km kyststrækning blev påvirket (kun en femtedel af Danmarks samlede kyststrækning), og kun $2 \%$ af hele Sri Lankas samlede areal. blev sat ind umiddelbart efter katastrofen, koncentrerede sig om at sikre de overlevende, sørge for lægehjælp, medicin, mad, vand og læ til de nødstedte og hjemløse. Relativt hurtigt stod det imidlertid klart, at vandforsyningen krævede en særlig indsats pga. sammenbrud af tidligere eksisterende 


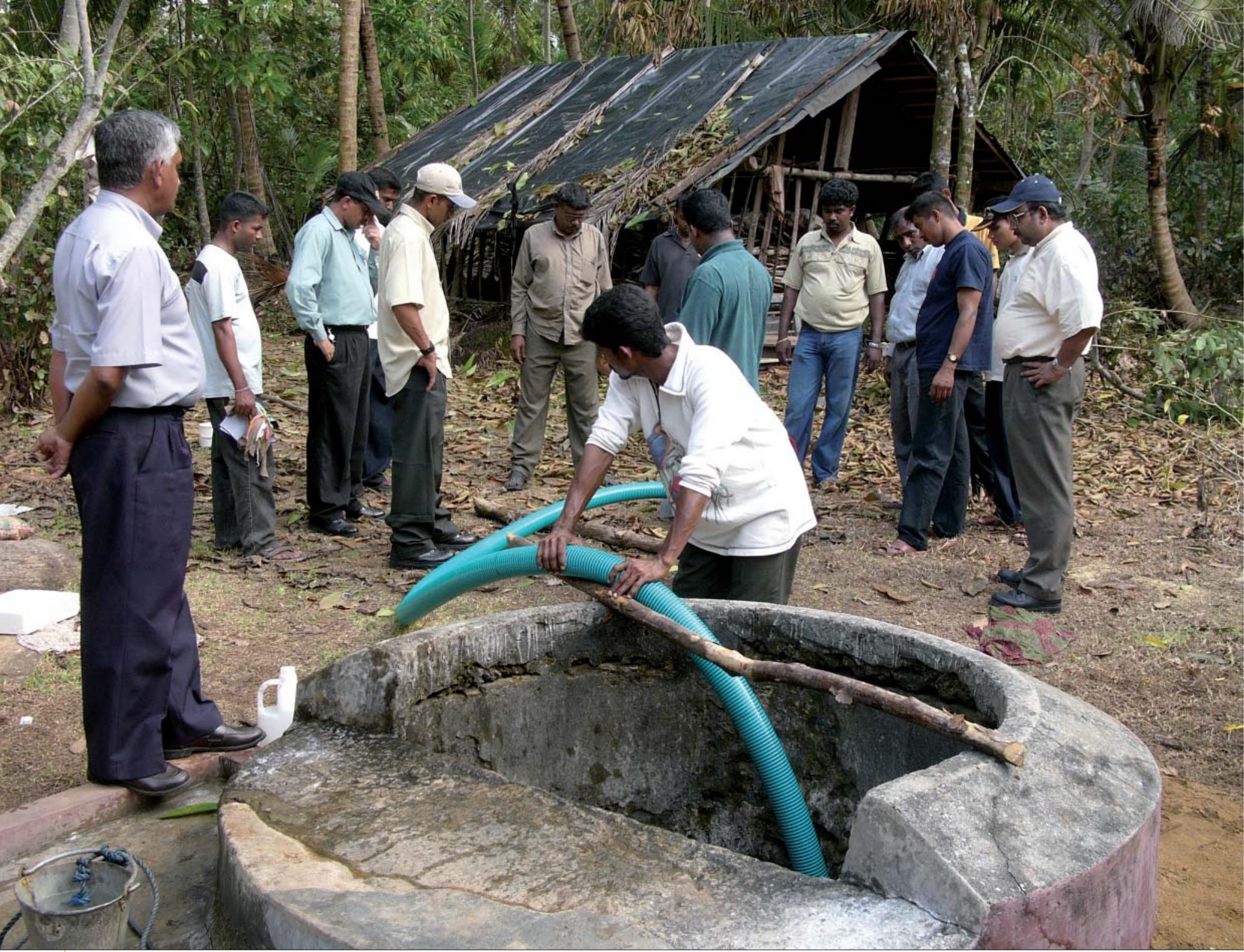

Typisk åben privat brønd. Hér ses et forsøg på oprensning efter tsunamien. (Foto: J. M. Christensen)

rørlagte systemer og specielt den udbredte saltvandsindtrængning, der havde fundet sted med havbølgernes overskylning, gjorde, at praktisk taget alle lokale åbne brønde var blevet salte.

Imodsætning til de rørlagte systemer, som for hovedpartens vedkommende var baseret på overfladevand fra indlandskilder (naturlige eller inddæmmede søer), og som hurtigt blev udbedret, forholdt det sig anderledes med den lokale vandforsyning via brønde.

Hovedparten af kystbefolkningen uden for de lidt større byer er sikret vand til drikkevand og andre formål via private, lave (ca 3,5 m dybe), åbne brønde, som trækker vand fra de omgivende, lokale grundvandsmagasiner (foto ovenfor). Man regner med, at et sted mellem 40.000 og 100.000 brønde blev ødelagt eller forsaltet som følge af tsunamien.

\section{Sri Lankas geologi}

Store strækninger af kysterne, op til nogle kilometer indlands, består af sandige, porøse strandsedimenter (figuren til højre), der fungerer som effektive overfladenære ferskvandsaquiferer (aquifer $=$ grundvandsmagasin, altså porøst medie, der kan holde vand), der har været udnyttet igennem generationer til vandforsyning for de lokale. Disse kvarternære sedimenter overlejrer fast klippegrund i ca. 20-40 m's dybde, der består af krystallinsk metamorf klippe fra Prækambrium. Disse undergrundsklipper er en del af et større landkompleks, der strækker sig ud under det meste af Sri Lanka. Det giver anledning til ringe aquiferer, undtagen der hvor det, som langs kysterne,

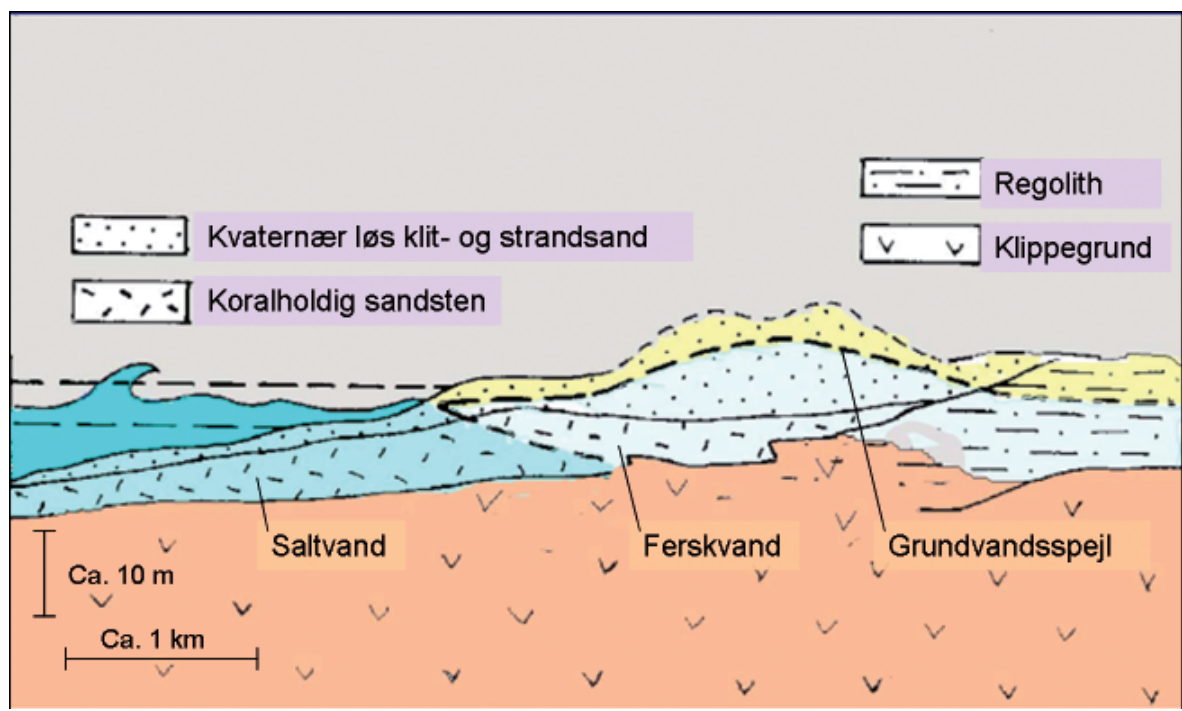

Typisk geologi på Sri Lankas østkyst: (Grafik: H. A. Dharmagunawardhane) 
er overlejret af sand, eller kridt som i nogle nordvestlige egne, løse alluviale aflejringer som langs historiske og nuværende floder. Størstedelen af indlandsområderne er dækket af forvitret klippeundergrund, som omdannes til opsprækkede delvist porøse regolith-jorde (løst materiale), der giver ringe grundvandsmagasiner. Som sådan er kystaquifererne, skønt ringe i udstrækning, meget centrale for vandforsyningen, da indlandsaquifererne er ringe, og vand til vandforsyning i disse områder primært opsamles fra regn og overfladeafstrømning til kunstige søer.

\section{Tsunamiens påvirkning af grundvandet}

Tsunamien påvirkede de sandige kystaquiferer på flere forskellige måder, der især forsaltede grundvandet (se numrene på figuren til højre):

1. Via infiltration fra jordoverfladen af saltvand under og umiddelbart efter tsunamibølgernes overskylning

2. Via oversvømmelse af de åbne brønde, som blev fyldt med saltvand

3. Via oversvømmelse og opfyldning af småsøer og lavninger i terrænet med saltvand, som senere infiltrerede til grundvandet

4. Erosion af kysten, som påvirkede vegetation, overfladelag, topografi og kystlinie lokalt, og dermed infiltrationsevnen og muligvis balancen mellem salt- og ferskvand $i$ kystbræmmen

På grund af hurtig og effektiv assistance forekom der ingen sygdomsepidemier blandt befolkningen som følge af tsunamien. Vandforsyningen blev langt hen ad vejen sikret ved hjælp af "tankers" (lastbiler med store vandtanke, foto nedenfor), der bragte vand til de nødstedte via store beholdere opstillet i landsbyerne.

En stor indsats blev gjort for at oprense brøndene (foto på foregående side) og genvinde frisk drikkevand fra disse. Imidlertid viste det sig ofte, at brøndene forblev salte, og oprensningen kun havde en mental effekt, der gjorde at folk igen turde bruge

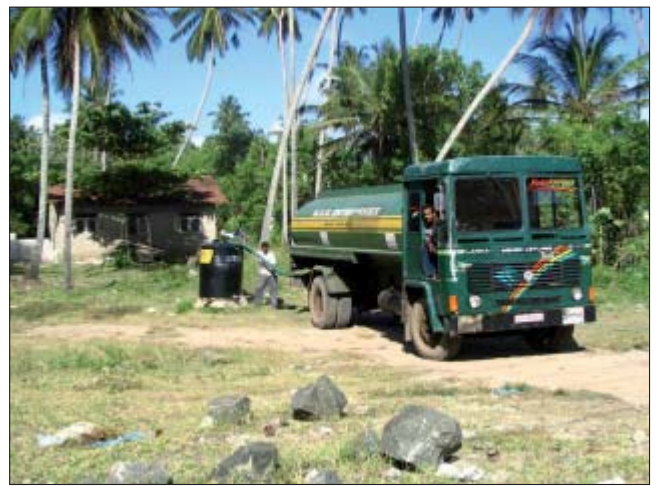

Nødhcelpsforsyning af drikkevand til de ramte efter tsunamien (Kilde: J. Obeysekera)

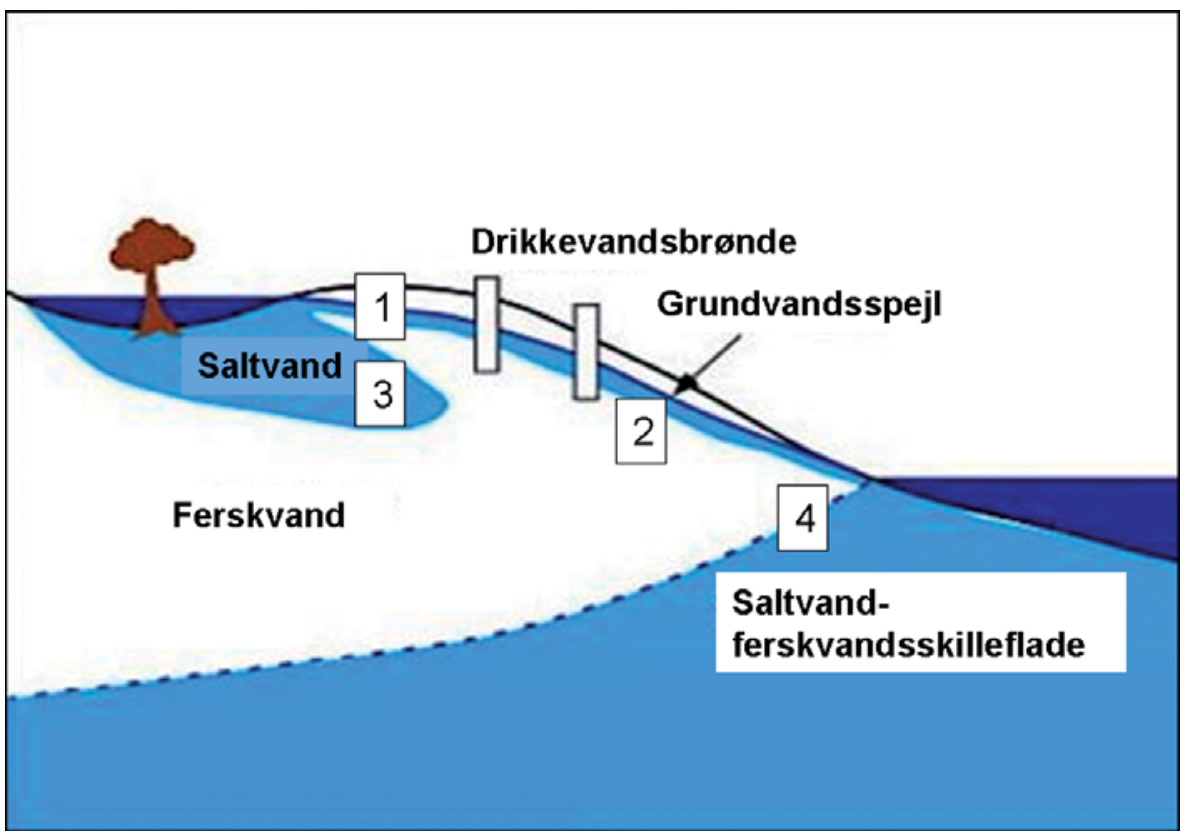

Forskellige påvirkniger af grundvandet forårsaget af tsunamien. For numre, se teksten. (Grafik: C. Harley)

vandet (til vask og badning), foruden at sediment og flydende affald, som var landet i brøndene, blev fjernet. Ofte blev brøndene også chock-chloreret for at sikre, at den bakterielle standard var i orden, i hvert fald for et stykke tid. Men mange af brøndene forblev som sagt for salte og blev enten ikke brugt eller kun til andre formål end drikkevand, og der var udsigt til at skulle forsyne områderne med drikkevand via tankers $i$ et ukendt antal måneder.

IWMI's indsats for at redde grundvandet På denne baggrund satte IWMI, International Water Management Institute, som har hovedkvarter på Sri Lanka, ind for at støtte processerne vedrørende koordinering og optimering af oprensningen af brøndene, information til lokale aktører omkring grundvandets påvirkning fra tsunamien og for at monitere saltholdigheden i brøndene over tid for at få en ide om udsigterne til at genvinde frisk drikkevand og udfase nødhjælpsforsyningen. Møder blev holdt med NGO'er (Non-Governmental Organizations) og lokale myndigheder i områderne på østkysten, specielt i distrikterne Trincomalee, Batticaloa og Ampara, som var særdeles hårdt ramt.

Her blev det forklaret, hvordan saltvand generelt, uden en tsunami, påvirker grundvand i kystområder, som de ramte, og specielt hvordan saltvandsindtrængning fra en tsunami måtte forventes at påvirke brønde og grundvand. Udfra teoretiske overvejelser, sparsomt kendskab til de lokale aquiferer, generel viden om saltvandsinfiltration, og diskussion af tidlige erfaringer fra områderne omkring pumpning og rensning af brøndene, blev der opstillet nogle forholdsvis simple retningslinier og anbefalinger for, hvorledes man optimerede oprensningen og undgik yderligere problemer, fx med forøget saltvandsindtrængning

\section{Forskel på saltvand og ferskvand}

Havvand, som har et højt saltindhold, har en større massefylde end ferskvand, eller sagt populært, er tungere end ferskvand. Dvs., når saltvand, $i$ dette tilfælde fra tsunamien, trænger ned i jorden og møder ferskvandet $i$ grundvandet nedenunder, så vil det have en tendens til at synke igennem det ferske vand, fremfor at blande sig jævnt med det, og bevæge sig mod bunden af aquiferen. Det samme skete i brøndene, hvor vandet hurtigt efter tsunamien var mere salt $i$ bunden end $i$ toppen, fordi det tunge saltvand var sunket ned. Dette fænomen har formentlig afhjulpet katastrofens omfang i form af grundvandets påvirkning. Meget af saltvandet er sikkert hurtigt sunket delvist igennem det friske vand og har efterladt det mindre salt, end hvis det var blevet opblandet helt med det. Den ukoordinerede oprensning af brøndene har formentlig kun forøget denne opblandingsproces, og således snarere forværret end afhjulpet situationen. 


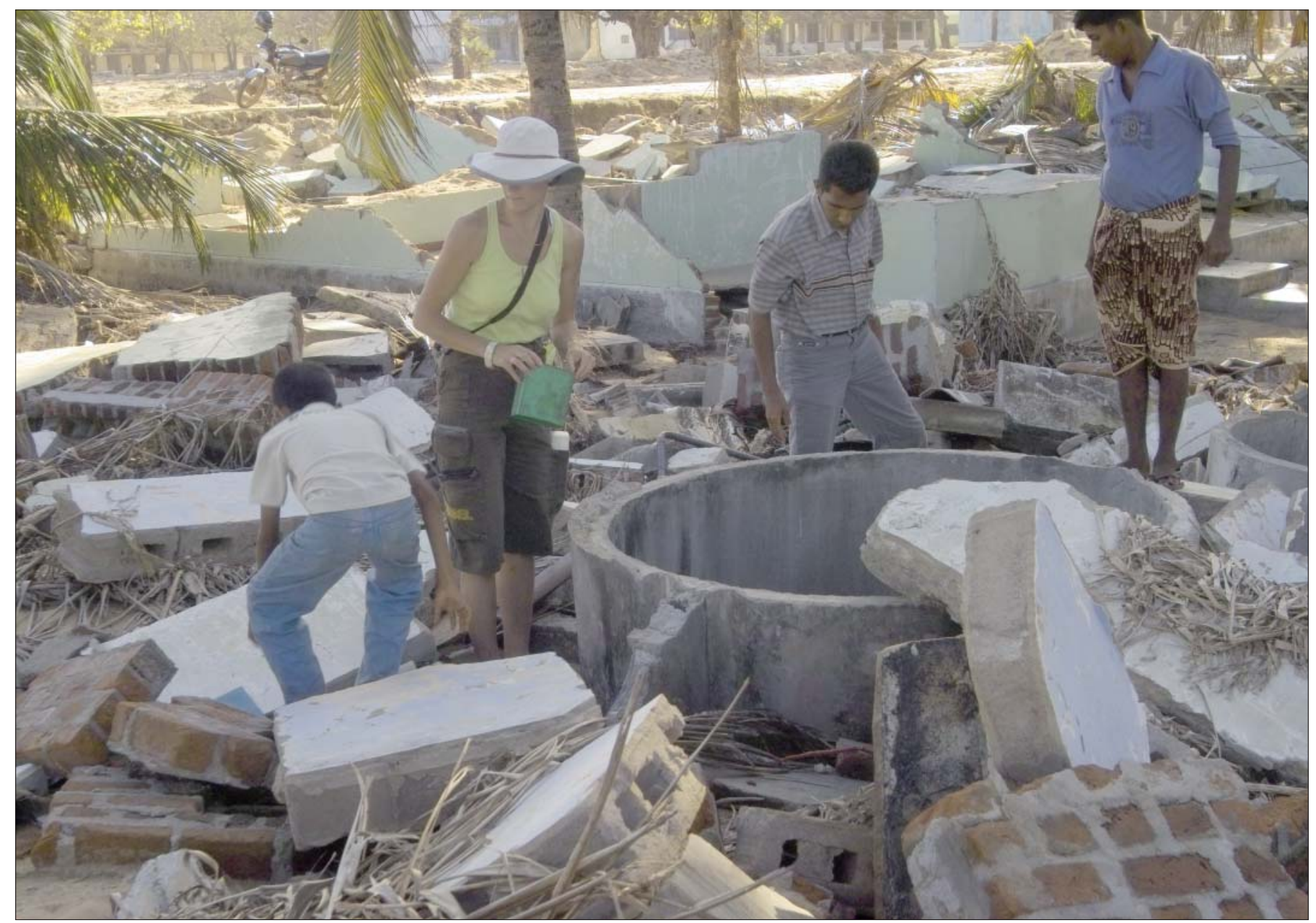

Monitering af saltholdigheden i en af de åbne brønde på østkysten af Sri Lanka kort tid efter tsunamien. (Foto: E. Eriksen, 2005)

\section{Oprensning af brøndene}

Oprensning og fjernelse af saltvandet $i$ brøndene efter tsunamien viste sig aldeles vanskelig og i de fleste tilfælde omsonst, selv om enorme resourcer blev sat ind på det. Det skyldtes, at grundvandet generelt, og ikke kun brøndene, var påvirket af saltvandindtrængning, således at fjernelse af saltvand fra brøndene simpelthen blev erstattes med nyt saltvand fra omkringliggende grundvand. Desuden blev oprensningen, som primært bestod i oppumpning og fjernelse af brøndvand, udført med simple og ikke videnskabeligt baserede metoder. Fx afledte man det oppumpede saltvand umiddelbart i nærheden af brøndene (se fotoet på side 21), hvilket blot recirkulerede saltvandet og således forlængede effekten. Desuden pumpede man for stærkt, hvilket foruden at ødelægge boringerne selv, kunne medføre indtrængning fra det underliggende permanente salte grundvand (figur nederst på side 21).

Endelig blev indsatsen formentlig indsat for sent, forstået på den måde, at det koncentrerede saltvand, som blev fanget $\mathrm{i}$ boringerne, allerede nåede at synke og forsvinde ud i det omgivende grundvand, inden oprensningen blev iværksat. Således var forsaltningen delvist afhjulpet ad naturlig vej, skønt brøndene desværre viste sig stadig at have for højt saltindhold til drikkevand. An- befalingerne mht. oprensning af brøndene gik således på at undgå at forlænge og forværre problemerne ved at henvise til moderat pumpning, mest med henblik på at fjerne generelt snavset vand, og opnå en acceptabel vandkvalitet til andre formål, foruden at tilfredsstille befolkningens ønsker om at fjerne tsunamivandet, som retteligt blev forbundet med sygdom og ødelæggelse.

\section{Monitering af saltvandsindhold $i$ boringer} IWMI tog de første målinger af saltholdigheden i enkelte brønde allerede midt i januar 2005 (foto ovenfor) og fandt ekstremt høje værdier. I marts måned påbegyndtes et mere systematisk moniteringsprogram, som dækkede ca. 150 brønde i tre forkellige områder i Batticaloa og Ampara distrikt med forskellig befolkningstæthed og arealanvendelse og med gentagne målinger med månedlige intervaller. Allerede inden for de første par måneder efter tsunamien skete der en mærkbar forbedring af den gennemsnitlige saltholdighed i brøndene, omkring en faktor 10 , formentlig pga. en hurtig nedsynkning af det tungere saltvand i brøndene (boksen på foregående side) og det omgivende grundvand og de naturlige opblandingsmekanismer, der har tendens til hurtigt at udjævne store koncentrationsgradienter mellem

\section{Saltholdighed i drikkevand}

Der findes ingen faste standarder for maksimalt saltindhold i drikkevand. Det er, fordi saltvand ikke er sundhedsskadeligt for mennesker i de koncentrationer, som generelt accepteres som drikkeligt. Desuden er saltindhold ikke en entydig parameter, som afhænger af hvilke komponenter, eller nærmere bestemt ioner, som den udgøres af. Endelig er aceptabel saltholdighed i drikkevand en smagssag, forstået på den måde, at nogle mennesker, som for eksempel befolkningen på østkysten af Sri Lanka, generelt, også før tsunamien, er vant til at drikke delvist saltvand, som kan forekomme i tørtiden, når salte opkoncentreres i grundvandet og i brøndene. I IWMIs undersøgelser, fandt man, at en saltholdighed på 1000 $\mu \mathrm{S} / \mathrm{cm}$ var en gennemsnitlig værdi for acceptabel drikkevandskvalitet. 


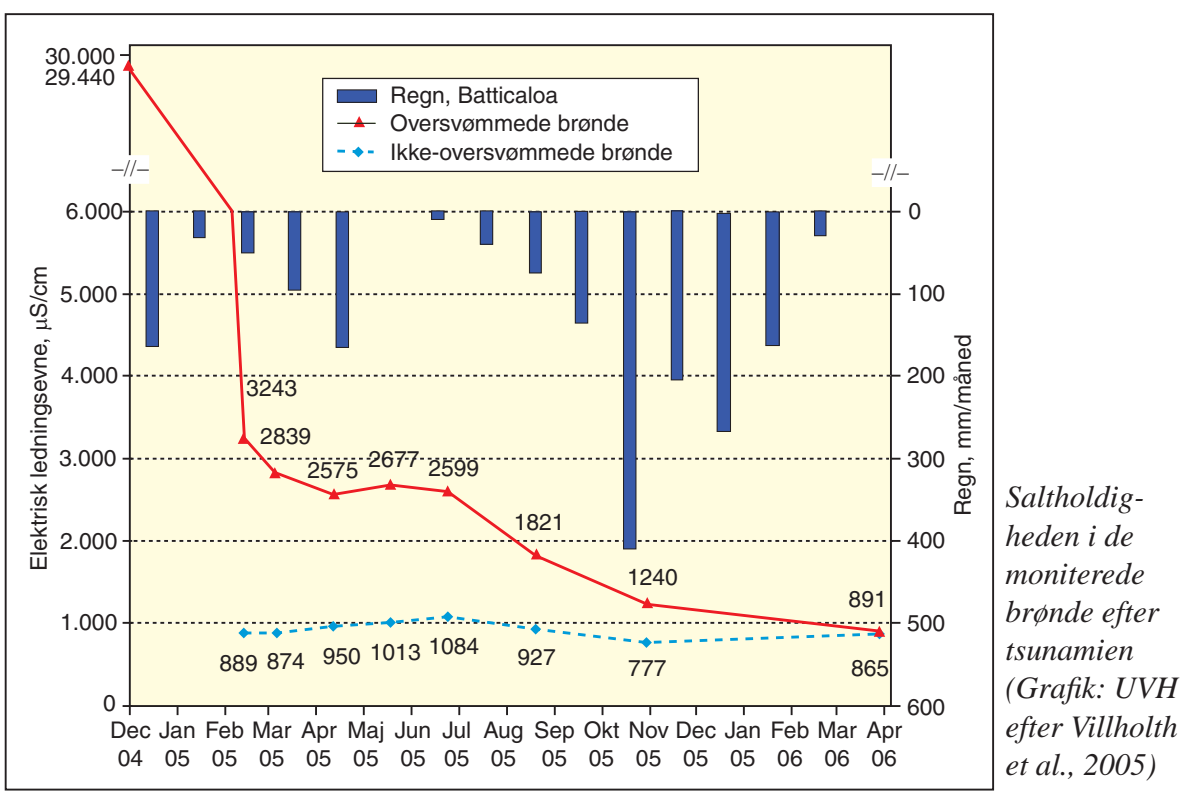

brøndene og det dybere og omkringliggende grundvand.

Brøndvandet var dog stadig for salt til drikkevand (se boksen på foregående side), og over de efterfølgende mange måneder, ca. et halvt år, skete der ikke nogen væsentlig overordnet forbedring af vandkvaliteten (figuren ovenfor). Dette skyldes, at saltindholdet $\mathrm{i}$ grundvandet og brøndene blev gradvist mere udjævnet, således at variabiliteten blandt brøndende faldt, men gennemsnitsindholdet forblev næsten konstant. Desuden forekom der ikke nogen yderligere fortynding fra rent vand, da det var tørtid i denne periode, og det således ikke regnende. $\mathrm{Da}$ regntiden satte ind i oktober-november måned, sporedes en signifikant forbedring af saltholdigheden, og over de efterfølgende måneder og frem til april 2006 nåede brøndene i gennemsnit en saltholdighed, der var acceptabel til drikkevand. På dette tidspunkt var saltholdigheden i de brønde, der var blevet overskyllet og fyldt af havvand under tsunamien, stort set den samme som i de brønde, der lå uden for de overskyllede områder, hvilket var et tegn på, at tsunamieffekten var ovre.

I nogle områder var brønde, der ikke var blevet overskyllet af tsunamien, dog blevet forsaltede efter tsunamien, hvilket forvirrer billedet lidt. Det skyldtes, at grundvandsstrømningen var indlands i stedet for mod havet i et område med en kystlagune. Ligeledes forblev nogle overskyllede brønde for salte, og således var der stadig nogle lokale spor, som formentlig tog længere tid at overkomme, eller som kun ville ændres ved ændrede pumpingsstrategier, idet for stærk pumping fra enkeltboringer kunne trække saltvand ind fra omkringliggende eller dybere salte lag.

Hvad så nu, ca 1 1/2 år efter tsunamien? Tsunamien rettede opmærksomheden på drikkevandet, specielt fra grundvand i de srilankanske kystområder. Effekterne fra saltvandsindtrængningen er delvist aftaget som følge af fortynding og erstatning fra nedsivende regnvand i mange områder, skønt lokale langtidseffekter må forventes. Nødhjælpsvandforsyningerne er under udfasning, og hjemløse folk, som blev forflyttet til lejre eller nye boliger, bliver gradvist forsynet via mere permanente løsninger. Erfaringerne fra nødhjælpsarbejdet og udfasningen bliver nu opsamlet af internationale NGO'er i samarbjede med IWMI og et lokalt universitet - således at erfaringerne kan komme fremtige nødhjælpssituationer til gode specielt, men ikke kun relateret til tsunamihændelser. Desuden har tsunamien løftet sløret for grundvandsmagsinernes skrøbelighed over for andre typer påvirkninger og forureninger. Der gøres således ligeledes en indsats for nøjere at kortlægge disse ressourcer og beregne optimale udnyttelsesstrategier, bl.a. i samarbejde med Geologisk Institut på Københavns Universitet og en række partnere i Sri Lanka og USA ${ }^{[\mathrm{c}]}$.

\section{Referencer:}

[a] GeologiskNyt, nr.1 , Feb. 2005. Tema: Summatra-jordskcelvet.

[b] Villholth et al., 2005. Tsunami Impacts on Shallow Groundwater and Associated Water Supply on the East Coast of Sri Lanka. Colombo, Sri Lanka. International Water Management Institute (IWMI). ISBN 92-9090-622-7. 68 pp. http://www.iwmi. cgiar.org/

[c] Illangasekare, T., S.W. Tyler, T.P. Clement, K.G. Villholth, A.P.G.R.L. Perera, J. Obeysekera, A. Gunatilaka, C.R Panabokke, D.W. Hyndman, K.J. Cunningham, J.J. Kaluarachchi, W. W-G. Yeh, M-R Van Genuchten, and K.H. Jensen, 2006. Impacts of the 2004 Tsunami on Groundwater Resources in Sri Lanka. Water Resources Research, 42(5). W05201, doi:10.1029/ 2006WR004876. 